\title{
"The Effect Of Particle Size Distribution (Psd) Concept Of Coarse Aggregates On The Water Demand Of The Concrete Mix"
}

\author{
Dr. Khalid, A. A. \\ Zakaria \\ Professor
}

\author{
Ghanim, H., Koja \\ Lecturer
}

Nadiya, S. I., Al Saffar

Assistant lecturer

Civil Eng. Dept.

\begin{abstract}
The effect of particles size distribution of the coarse aggregates on the water demand of the concrete mix was studied and analyzed using the concept of particles size distribution in so far as they deviate from the avera size or fineness modulus as indicated by the standard deviation of the sample.

Six concrete mixes $1: 2: 4$ by weight $(320 \mathrm{~kg} / \mathrm{m} 3$ cement content) were designed for a given slump of (30-60) $\mathrm{mm}$. The main variable being the gradation of the coarse aggregates.

The results showed that an increase in the S.D of the coarse aggregate particle distribution resulted in an increase in the water demand of the mix, this was further substantiated by a decrease in the resulting compressive strength. An extra 38 similar concrete mixes were selected randomly from the literature for further supporting evidence.
\end{abstract}

Keywords: Particle size distribution, Water demand, standard deviation, average size of aggregate

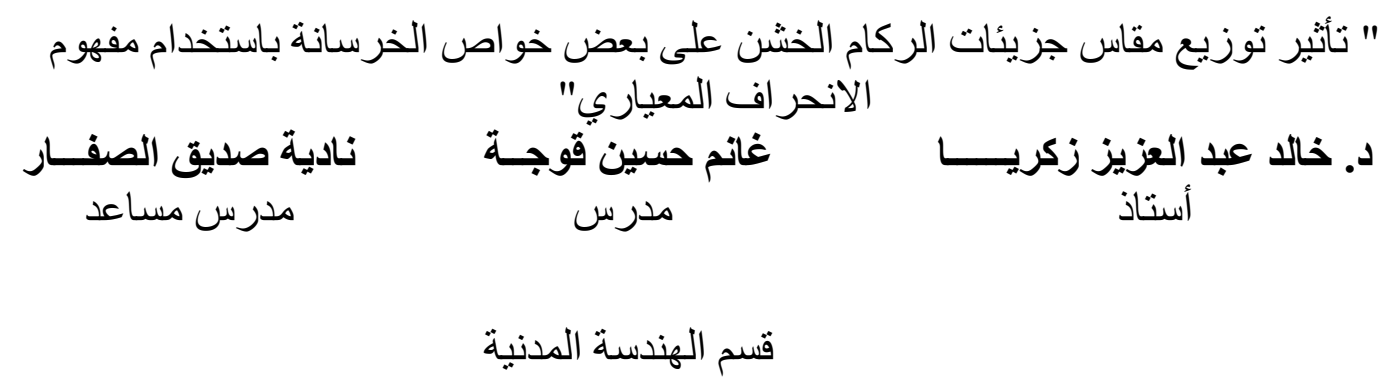

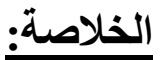




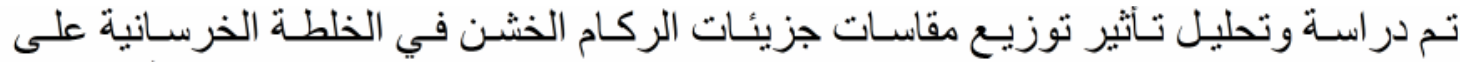

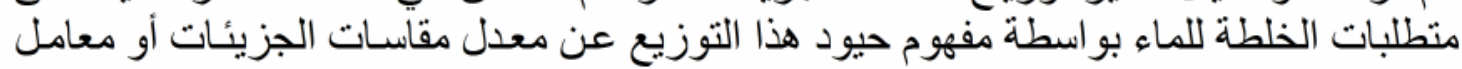

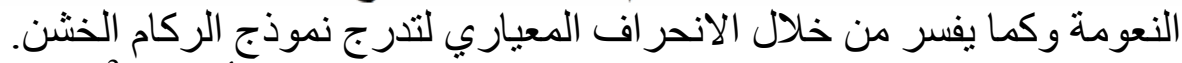

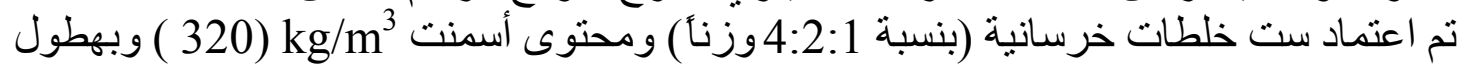

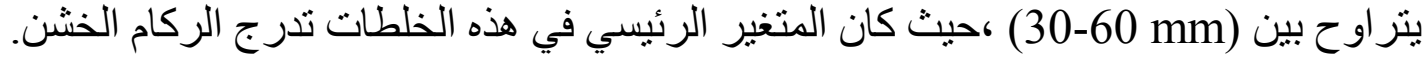

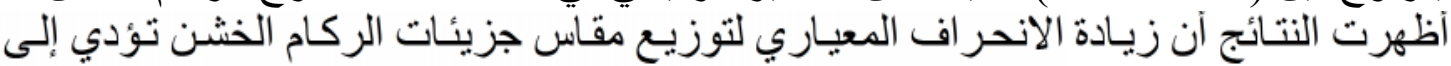

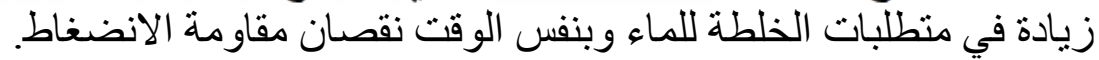

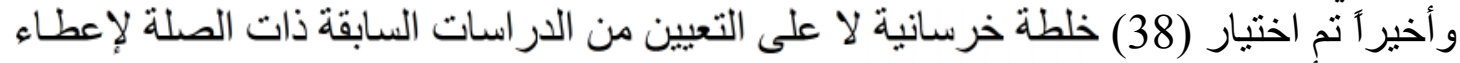

\section{Introduction:}

$$
\text { إثباتات و أدلة إضافية. }
$$

Received rq June 2005

Accepted 11 July 2006

For fully compacted concrete, $w / c$ ratio is the main parameter governing the strength of concrete, according to the law established by Abram [1], and his initial statement, "the strength of concrete is a function of the ratio of cement to the free water in the plastic mixture", agrees with the fact that the strength of concrete continues to increase with the reduction of $\mathrm{w} / \mathrm{c}$ ratio to a value of 0.2 or even lower.

At equal values of w/c ratios, the strength of workable concrete may be influenced greatly by such factors as the grading, relative amount of aggregates, the shape, surface texture, stiffness, and the maximum size of aggregates.

A suitable gradation [2] of the combined aggregate in a concrete mix is described in order to secure workability and to secure economy in the use of cement. A well-graded mixture produces strong concrete than a harsh or poorly graded one. Singh [3] has proposed that, for constant mix proportions, the increase in specific surface (index of grading) of the aggregate, causes a decrease in the amount of cement relative to the surface of the aggregate, thus causing more voids around the surface of the aggregate particles and decrease in strength.

Specific surface gives in somewhat misleading picture of the workability to be expected and to overcome this difficulty, Murdock [4] has suggested the use of surface index, which is an empirical number, related to the specific surface of the particles with more weightage assigned to the coarser material. 
The total surface index (fs) of a mixture of aggregates is calculated by multiplying the percentage weight of material retained on each sieve and the corresponding surface index and to their sum is added a constant of 330 and the result is divided by $1000[5]$.

The specific surface varies with different types of aggregate due to variations in the angularity. The angularity index (fa) depends upon the grading of coarse and fine aggregates, angularity number [6] and the relative proportion of coarse and fine aggregates in the mix.

The experimental evidence presented and mathematical analysis clearly shows that the importance of fineness modulus is greatly underrated nowadays. The limit of validity of this method is much wider and its applicability is much better than is generally believed [7].

The grading is characterized numerically by the fineness modulus. This makes possible the development of formula to express the effect of grading on the concrete properties [1]. The fineness modulus represents an average particle size of the aggregate and, as such, it is a fundamental parameter of the particle size distribution.

Both the fineness modulus and the specific surface are measures of average particle size. Experimental results, however, show better correlation with fineness modulus [7].

All normal concretes containing the optimum coarse aggregate content (for workability) have fine aggregate to cement ratios well in excess of (0.8). The more frequent cause for losses in strength is at the other extreme: because the critical maximum value is exceeded, incomplete compaction occurs. However, for all practical purposes, when the optimum coarse aggregate is being used, these extreme conditions of either too little or too much fine aggregate are readily avoided [8].

Increasing the proportion of the rounded particles decreases the 
percentage of voids. Since the cement paste required for concrete is proportional to the void content of the combined aggregates, it is desirable to keep the void content to a minimum $[9,15]$.

Researchers $[10,11]$ have suggested that, an increase in the maximum aggregate size results in lower compressive strength in rich mixes and higher compressive strength in leaner mixes. At a given $\mathrm{w} / \mathrm{c}$ ratio and $\mathrm{mix}$ proportions, concrete with smaller maximum aggregate size develops greater strength than concrete with larger size [12]. The particle size distribution (as they deviate from the fineness modulus is indicated by the standard deviation of the aggregate particle) [13].

Statistical analysis indicates that the lower the value of the standard deviation, the higher will be the percentage of particles close to the average size, conversely a higher standard deviation indicates a larger portion of particles in the coarse and fine fractions.

If the coarse aggregate is regarded as standard, i.e., kept unchanged throughout a series of tests, it will be found that the use of different sands in the mix results in different water demands. Consequently, it may be referred to the "water demand of the sand". On the other hand, if the sand is regarded as standard the use of different coarse aggregate in the mix also results in different water demand and it may then be referred to the "water demand of coarse aggregate", [12].

\section{Objective of the Research:}

The object of the current work is to show that the particles size distribution of the coarse aggregate using the concept of standard deviation has a definite effect on the mix water demand and ultimately on the concrete compressive strength. 


\section{Experimental Program:}

Materials used: -

Locally available materials were used. Their main properties are as indicated below:

Cement: the cement used was in accordance with Iraqi specification (IQS) No. 5 (1984) [16].

Fine aggregates: Fine aggregates used consisted of medium normal river sand in accordance B.S. 882-(1992) [17].

Coarse aggregates: Coarse aggregates used were normal river gravel (irregular, almost rounded) in accordance with B.S. 882-(1992) [17].

Table (1) shows some relative properties with the sieve analysis of the used coarse aggregate.

Table (1) Relative properties \& grading of coarse aggregates -according to

B. S. $882-1992$

\begin{tabular}{|c|c|c|c|c|c|c|c|}
\hline $\begin{array}{c}\text { Siev } \\
\text { e } \\
\text { Ind } \\
\text { ex }\end{array}$ & $\begin{array}{l}\text { Sieve } \\
\text { Size } \\
(\mathrm{mm})\end{array}$ & $\begin{array}{c}\text { (1) } \\
\text { Grad } \\
\text { ed } \\
20 \mathrm{~m} \\
\mathrm{~m}\end{array}$ & $\begin{array}{c}\text { (2) } \\
\text { ungrade } \\
\text { d }\end{array}$ & $\begin{array}{c}(3) \\
\text { Grade } \\
d \\
20 \mathrm{~mm}\end{array}$ & $\begin{array}{c}(4) \\
\text { Grade } \\
d \\
20 \mathrm{~mm}\end{array}$ & $\begin{array}{c}\text { (5) } \\
\text { ungrad } \\
\text { ed }\end{array}$ & $\begin{array}{c}\text { (6) } \\
\text { UNES } \\
\underline{\text { CO }}\end{array}$ \\
\hline 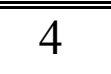 & $\overline{440}$ & $\begin{array}{ll}100 \\
\end{array}$ & $\begin{array}{ll}100 \\
\end{array}$ & $\begin{array}{ll}100 \\
\end{array}$ & $\begin{array}{ll}100 \\
\end{array}$ & $\overline{c 100}$ & $\begin{array}{ll}100 \\
\end{array}$ \\
\hline 8 & 20 & 95 & 90 & 98 & 100 & 95 & 90 \\
\hline 7 & 10 & 30 & 20 & 45 & 60 & 70 & 50 \\
\hline 6 & 5 & 0 & 0 & 5 & 10 & 65 & 10 \\
\hline
\end{tabular}




\begin{tabular}{|c|c|c|c|c|c|c|c|}
\hline 5 & 2.36 & 0 & 0 & 0 & 0 & 0 & 0 \\
\hline 4 & 1.18 & 0 & 0 & 0 & 0 & 0 & 0 \\
\hline 3 & $600 \mu_{\mathrm{m}}$ & 0 & 0 & 0 & 0 & 0 & 0 \\
\hline 2 & $300 \mu_{\mathrm{m}}$ & 0 & 0 & 0 & 0 & 0 & 0 \\
\hline 1 & $150 \mu_{\mathrm{m}}$ & 0 & 0 & 0 & 0 & 0 & 0 \\
\hline \multirow{\beta}{\wedge}{} & F.M & 6.75 & 6.9 & 6.52 & 6.3 & 5.7 & 6.5 \\
\hline
\end{tabular}

\section{Procedure}

The above mentioned materials were used in preparing six concrete mixes 1:2:4 by weight, cement content (320) $\mathrm{kg} / \mathrm{m}^{3}$, maximum aggregate size (20) $\mathrm{mm}$ and having a slump of (30-60) $\mathrm{mm}$. The main variable was the gradation of the coarse aggregates used as shown in Table (1).

For further evidence, number of mixes totaling 38 were chosen randomly from the literature $[12,14]$ designated No. 7 to No. 44 Table (3).

\section{$\underline{\text { Investigated Parameters }}$}

The main investigated parameters of the present research work are as follows: 
1. The standard deviation of the coarse aggregate particle size distribution was calculated, this is shown in col.3 of Table (3), and typical calculation is listed in Appendix (A).

2. The slump range for all the mixes considered with the w/c ratios (water demand of the mix) are given in col. 4 and 5 of Table (3) respectively. See also Figs (1, 2, and 3.)

3 . The 28-day experimental cube compressive strength of $100 \times 100 \times 100 \mathrm{~mm}$ cubes prepared, cured, and tested according to B.S 1881,1983 parts 108,111 , and 116 respectively is listed in col. 6 of Table (3).

4. The calculated compressive strength using the following equation which is predicted using the regression analysis on 44 test result from the present study and the published data as shown in Table (1) is given in col. 7 of Table (3); this equation has a correlation coefficient of (0.92).

$$
\sigma=96.69-112.1 \mathrm{~W} / \mathrm{C}-\mathbf{0 . 0 4 5} \mathrm{S}-9.81 \text { S.D }
$$

$\sigma=$ Calculated Compressive strength of concrete (MPa).

$\mathrm{W} / \mathrm{C}=$ Water cement ratio.

$\mathrm{S}=$ Slump (mm)

S.D $=$ Standard Deviation of aggregates.

5.Col. (8) shows the Cal./Exp. values of the compressive strength, see also Fig. (4).

6. Finally the $\mathrm{A} / \mathrm{C}$ ratios, which are the richness of the mixes considered, are shown in col.2 of Table (3). 


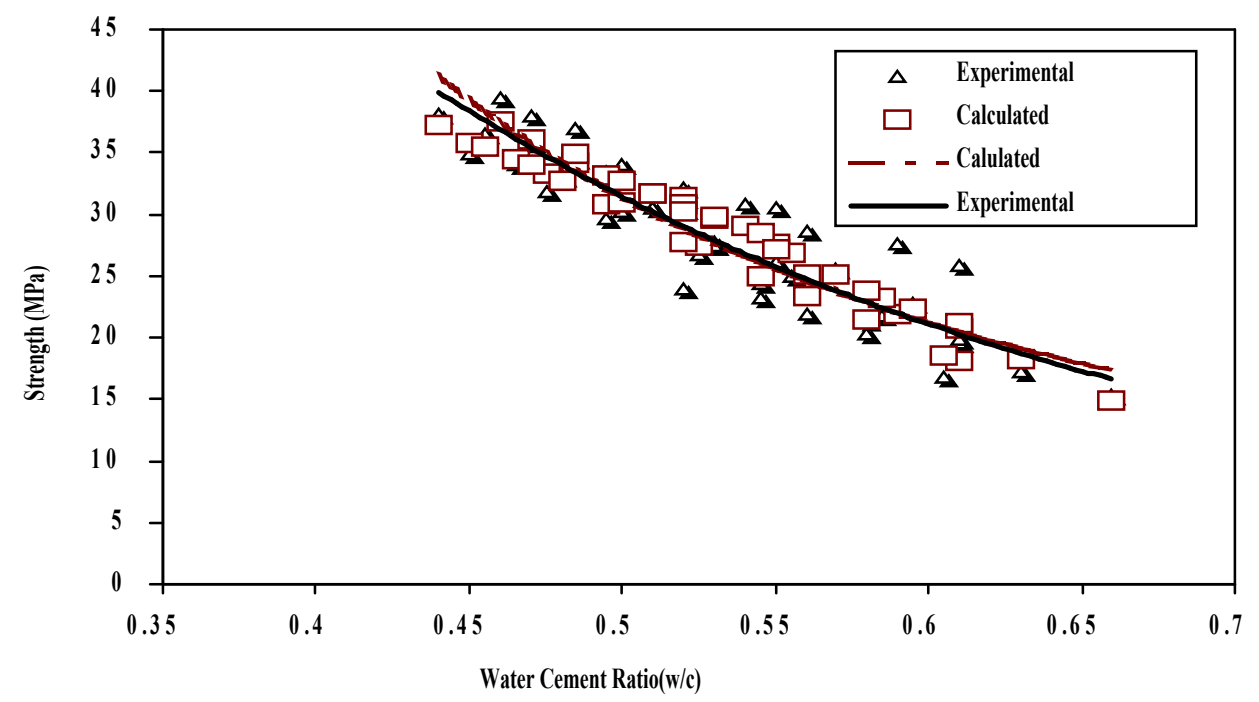

Fig. (1) Relationship between Water Cement Ratio and Cube Compressive Strength.

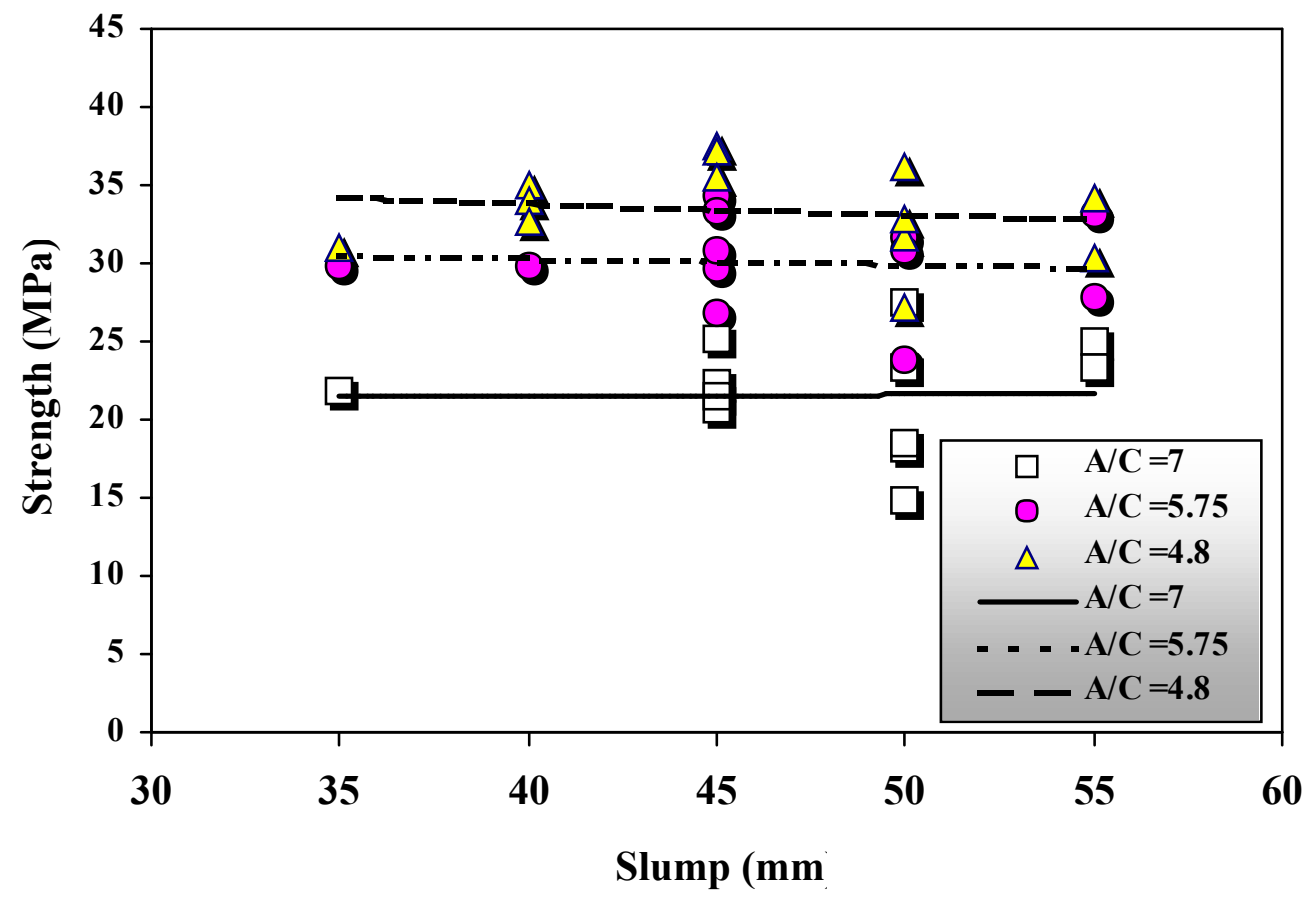

Fig. (2) Relationship between Slump and Compressive Strength. 


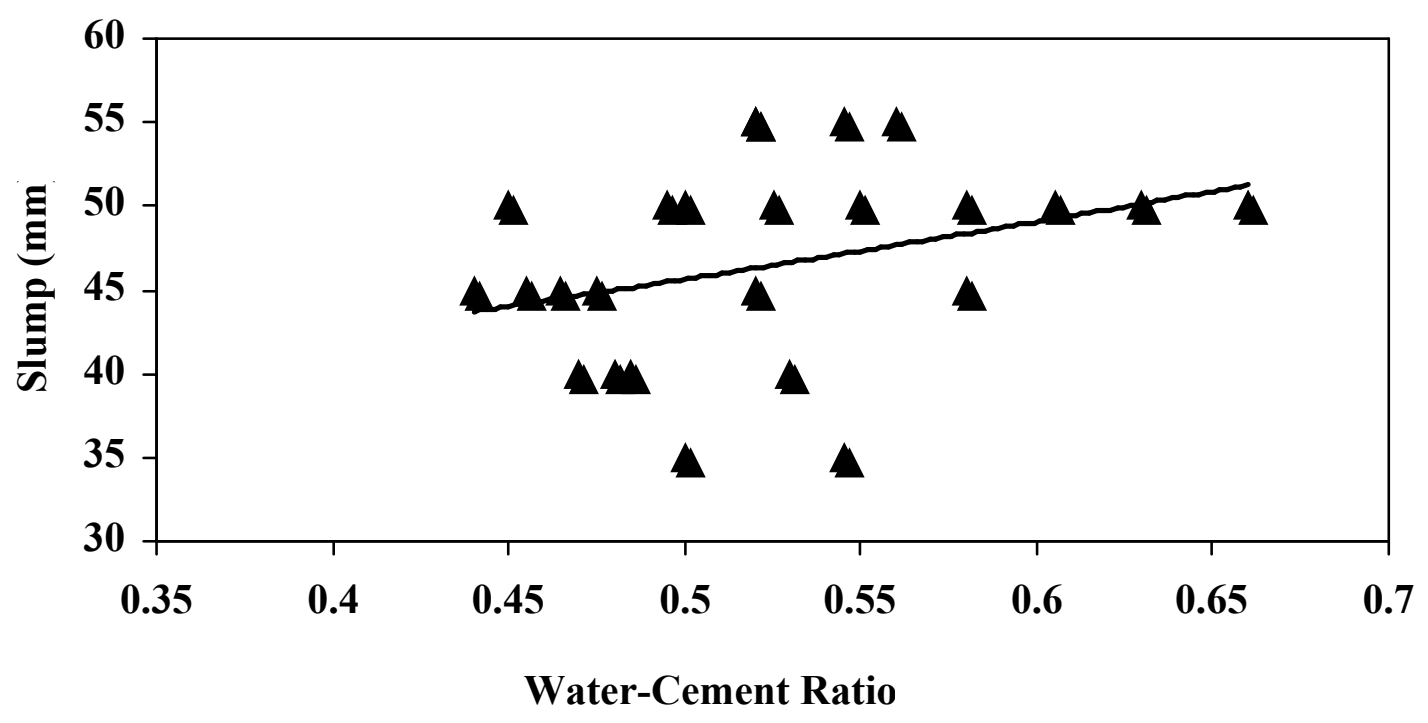

Fig. (3) Slump- Water Cement Ratio Relationship.

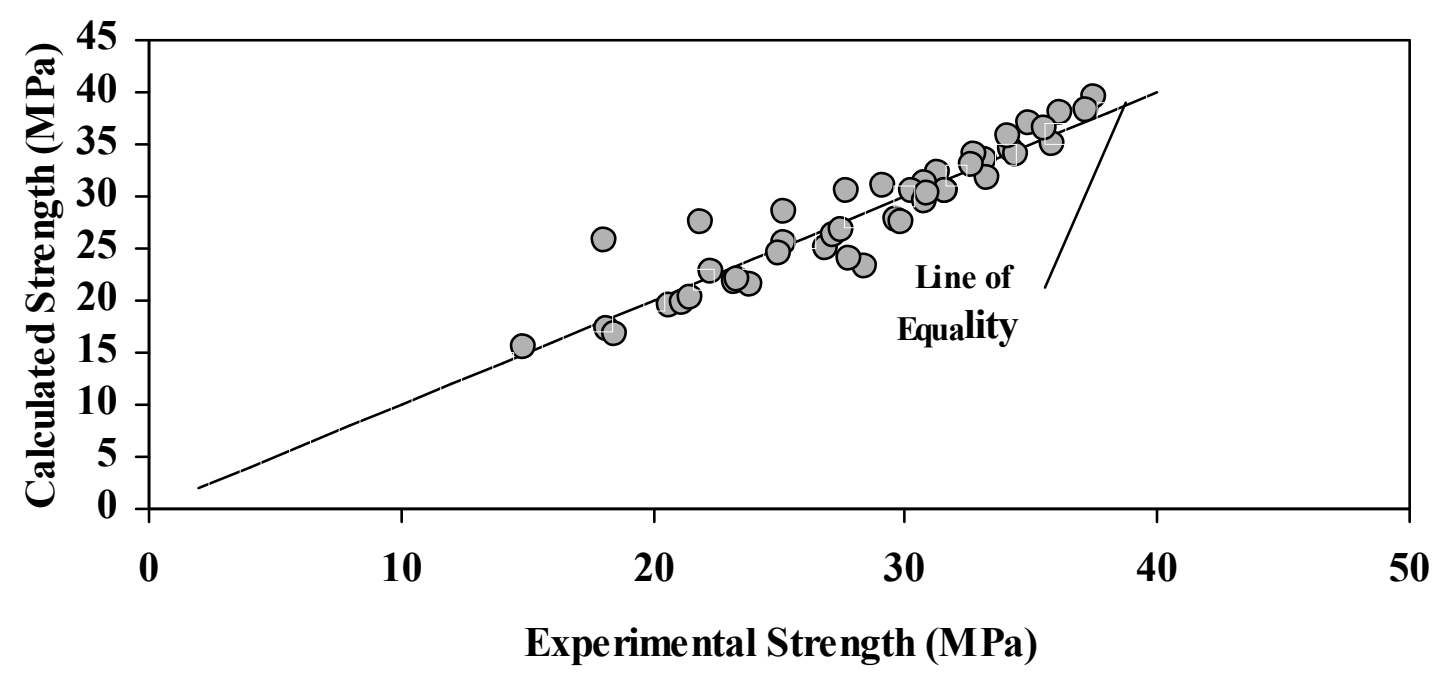

Fig. (4) Experimental -Calculated Compressive Strength. 
Table (2) Final main properties of the considered mixes in the present study.

\begin{tabular}{|c|c|c|c|c|c|c|c|c|c|}
\hline $\begin{array}{l}\text { M } \\
\text { ix }\end{array}$ & $\begin{array}{l}\text { F. } \\
\text { M } \\
\text { of } \\
\text { gra } \\
\text { vel }\end{array}$ & $\begin{array}{c}\text { Aver } \\
\text { age } \\
\text { sieve } \\
\text { size } \\
(\mathrm{mm})\end{array}$ & $\begin{array}{c}\% \\
\text { pass } \\
\text { ing } \\
\text { aver } \\
\text { age } \\
\text { sieve } \\
\text { size }\end{array}$ & $\begin{array}{r}\text { S.D } \\
\text { of } \\
\text { agg. } \\
\text { Parti } \\
\text { cles }\end{array}$ & $\begin{array}{c}\text { w/c } \\
\text { base } \\
\text { d on } \\
\text { S.S. } \\
\text { D } \\
\text { for a } \\
\text { give } \\
\text { n } \\
\text { slum } \\
\text { p }\end{array}$ & $\begin{array}{c}\text { Water } \\
\text { Demand } \\
\text { as } \\
\text { related } \\
\text { to S.D } \\
\text { and } \\
\text { average } \\
\text { Sieve } \\
\text { size }\end{array}$ & $\begin{array}{c}\sigma \\
7 \\
\\
\text { day } \\
\text { s } \\
\text { MP } \\
\text { a }\end{array}$ & $\begin{array}{l}\sigma \\
28 \\
\text { da } \\
\text { ys } \\
\text { M } \\
\text { Pa }\end{array}$ & $\begin{array}{c}\text { Type } \\
\text { of } \\
\text { agg. }\end{array}$ \\
\hline $\begin{array}{l}(1 \\
)\end{array}$ & $\begin{array}{c}6.7 \\
5\end{array}$ & $\overline{10}$ & $\overline{30}$ & 0.536 & 0.52 & $\begin{array}{c}\text { S.D } \\
\text { (Small) } \\
=\text { higher } \\
\% \text { of } \\
\text { particles } \\
\text { close to } \\
\text { average } \\
\text { sieve } \\
\text { size. }\end{array}$ & 21.0 & $\begin{array}{c}32 . \\
2\end{array}$ & $\begin{array}{c}\text { Grade } \\
\text { d }\end{array}$ \\
\hline $\begin{array}{l}(2 \\
)\end{array}$ & 6.9 & 10 & 20 & 0.538 & 0.54 & $\begin{array}{c}\text { S.D } \\
\text { (Small) } \\
=\text { higher } \\
\% \text { of } \\
\text { particles } \\
\text { closes to } \\
\text { average } \\
\text { sieve } \\
\text { size. }\end{array}$ & 21.2 & $\begin{array}{c}30 . \\
9\end{array}$ & $\begin{array}{c}\text { Ungra } \\
\text { ded }\end{array}$ \\
\hline $\begin{array}{c}3 \\
\text { (3) }\end{array}$ & $\begin{array}{c}6.5 \\
2\end{array}$ & 10 & 45 & 0.545 & 0.55 & $\begin{array}{c}\text { S.D } \\
\text { (small) } \\
\text { but } \\
\text { increase } \\
\text { s in } \\
\text { water } \\
\text { demand }\end{array}$ & 19.4 & $\begin{array}{c}30 . \\
5\end{array}$ & $\begin{array}{c}\text { Grade } \\
\text { d }\end{array}$ \\
\hline
\end{tabular}




\begin{tabular}{|c|c|c|c|c|c|c|c|c|c|}
\hline & & & & & & $\begin{array}{c}\text { due to } \\
\text { increase } \\
\text { in } \% \\
\text { passing } \\
\text { average } \\
\text { sieve } \\
\text { size. }\end{array}$ & & & \\
\hline $\begin{array}{l}(4 \\
)\end{array}$ & 6.3 & $\begin{array}{c}4.75 \\
10\end{array}$ & $\begin{array}{l}10 \\
60\end{array}$ & 0.64 & 0.56 & $\begin{array}{c}\text { S.D } \\
\text { (large) } \\
\text { indicatin } \\
\text { g large } \\
\text { proporti } \\
\text { on of } \\
\text { particles } \\
\text { in the } \\
\text { fine } \\
\text { fraction } \\
(60 \% \\
\text { passing } \\
\text { sieve } 10 \\
\text { mm) } \\
\text { further } \\
\text { increase } \\
\text { in water } \\
\text { demand. }\end{array}$ & 17.9 & $\begin{array}{c}28 . \\
6\end{array}$ & $\begin{array}{c}\text { Grade } \\
\text { d }\end{array}$ \\
\hline $\begin{array}{c}(5 \\
)\end{array}$ & 5.7 & $\begin{array}{c}5 \\
10\end{array}$ & $\begin{array}{l}65 \\
70\end{array}$ & 1.004 & 0.59 & $\begin{array}{c}\text { S.D } \\
\text { (large) } \\
\text { further } \\
\text { increase } \\
\text { in water } \\
\text { demand. }\end{array}$ & 16.5 & $\begin{array}{c}27 . \\
6\end{array}$ & $\begin{array}{l}\text { Ungra } \\
\text { ded }\end{array}$ \\
\hline $\begin{array}{c}(6 \\
)\end{array}$ & 6.5 & 10 & 50 & 0.82 & 0.61 & $\begin{array}{c}\text { S.D } \\
\text { (large) } \\
\text { large } \\
\text { proporti }\end{array}$ & 16.0 & $\begin{array}{c}25 . \\
8\end{array}$ & $\begin{array}{l}\text { Grade } \\
\text { d } \\
\text { (roun }\end{array}$ \\
\hline
\end{tabular}




\begin{tabular}{|l|l|l|l|l|l|}
\hline & & & ons of \\
particles \\
in the \\
fine \\
fraction \\
$(50 \%$ \\
\end{tabular}

Table (3) Main Investigated Parameters.

\begin{tabular}{||c||c||c|c||c||c|c|c||}
\hline \hline No. & $\begin{array}{c}\text { A/C } \\
\text { Ratio }\end{array}$ & S.D & $\begin{array}{c}\text { Slump } \\
(\mathbf{m m})\end{array}$ & $\begin{array}{c}\text { W/c } \\
\text { Ratio }\end{array}$ & $\begin{array}{c}\text { Strength } \\
\text { (exp.) }\end{array}$ & $\begin{array}{c}\text { Strength } \\
\text { (cal.) }\end{array}$ & Cal/Exp. \\
\hline \hline $1^{*}$ & 6 & 0.536 & 40 & 0.52 & 32.2 & 31.35 & 0.9736 \\
\hline $2^{*}$ & 6 & 0.538 & 40 & 0.54 & 30.9 & 29.09 & 0.94142 \\
\hline $3^{*}$ & 6 & 0.545 & 45 & 0.55 & 30.5 & 27.67 & 0.90721 \\
\hline $4^{*}$ & 6 & 0.64 & 55 & 0.56 & 28.6 & 25.16 & 0.87972 \\
\hline $5^{*}$ & 6 & 1.004 & 40 & 0.59 & 27.6 & 21.9 & 0.79348 \\
\hline
\end{tabular}




\begin{tabular}{|c|c|c|c|c|c|c|c|}
\hline $6^{*}$ & 6 & 0.82 & 50 & 0.61 & 25.8 & 18.12 & 0.70233 \\
\hline 7 & 7 & 0.5722 & 45 & 0.57 & 25.5 & 25.16 & 0.98667 \\
\hline 8 & 7 & 0.5722 & 50 & 0.585 & 21.8 & 23.26 & 1.06697 \\
\hline 9 & 7 & 0.5722 & 45 & 0.61 & 19.6 & 20.68 & 1.0551 \\
\hline 10 & 5.75 & 0.5722 & 55 & 0.495 & 33.4 & 33.11 & 0.99132 \\
\hline 11 & 5.75 & 0.5722 & 50 & 0.51 & 30.6 & 31.66 & 1.03464 \\
\hline 12 & 5.75 & 0.5722 & 45 & 0.53 & 27.8 & 29.65 & 1.06655 \\
\hline 13 & 5.75 & 0.5722 & 45 & 0.555 & 25 & 26.84 & 1.0736 \\
\hline 14 & 4.8 & 0.5722 & 45 & 0.46 & 39.5 & 37.49 & 0.94911 \\
\hline 15 & 4.8 & 0.5722 & 50 & 0.47 & 38 & 36.14 & 0.95105 \\
\hline 16 & 4.8 & 0.5722 & 55 & 0.485 & 34.5 & 34.23 & 0.99217 \\
\hline 17 & 4.8 & 0.5722 & 50 & 0.51 & 30.6 & 31.66 & 1.03464 \\
\hline 18 & 7 & 0.5722 & 45 & 0.595 & 22.8 & 22.36 & 0.9807 \\
\hline 19 & 7 & 0.5722 & 35 & 0.61 & 19.8 & 21.14 & 1.06768 \\
\hline 20 & 7 & 0.5722 & 50 & 0.63 & 17.2 & 18.21 & 1.05872 \\
\hline 21 & 7 & 0.5722 & 50 & 0.66 & 15.4 & 14.85 & 0.96429 \\
\hline 22 & 5.75 & 0.5722 & 45 & 0.52 & 31.3 & 30.77 & 0.98307 \\
\hline 23 & 5.75 & 0.5722 & 40 & 0.53 & 27.4 & 29.87 & 1.09015 \\
\hline 24 & 5.75 & 0.5722 & 35 & 0.545 & 23.2 & 28.42 & 1.225 \\
\hline 25 & 5.75 & 0.5722 & 50 & 0.58 & 21.4 & 23.82 & 1.11308 \\
\hline 26 & 4.8 & 0.5722 & 40 & 0.485 & 37 & 34.92 & 0.94378 \\
\hline 27 & 4.8 & 0.5722 & 50 & 0.5 & 34 & 32.78 & 0.96412 \\
\hline 28 & 4.8 & 0.5722 & 55 & 0.52 & 30.4 & 30.31 & 0.99704 \\
\hline 29 & 4.8 & 0.5722 & 50 & 0.55 & 26.2 & 27.18 & 1.0374 \\
\hline 30 & 7 & 0.829 & 50 & 0.525 & 26.7 & 27.46 & 1.02846 \\
\hline 31 & 7 & 0.829 & 55 & 0.545 & 24.4 & 24.99 & 1.02418 \\
\hline 32 & 7 & 0.829 & 55 & 0.56 & 21.9 & 23.31 & 1.06438 \\
\hline 33 & 7 & 0.829 & 45 & 0.58 & 20.3 & 21.52 & 1.0601 \\
\hline
\end{tabular}




\begin{tabular}{|c|c|c|c|c|c|c|c|}
\hline 34 & 7 & 0.829 & 50 & 0.605 & 16.8 & 18.49 & 1.1006 \\
\hline 35 & 5.75 & 0.829 & 50 & 0.45 & 34.9 & 35.86 & 1.02751 \\
\hline 36 & 5.75 & 0.829 & 45 & 0.465 & 34 & 34.41 & 1.01206 \\
\hline 37 & 5.75 & 0.829 & 45 & 0.475 & 31.8 & 33.29 & 1.04686 \\
\hline 38 & 5.75 & 0.829 & 50 & 0.495 & 29.6 & 30.82 & 1.04122 \\
\hline 39 & 5.75 & 0.829 & 55 & 0.52 & 24 & 27.79 & 1.15792 \\
\hline 40 & 4.8 & 0.829 & 45 & 0.44 & 38.2 & 37.21 & 0.97408 \\
\hline 41 & 4.8 & 0.829 & 45 & 0.455 & 36.5 & 35.53 & 0.97342 \\
\hline 42 & 4.8 & 0.829 & 40 & 0.47 & 35.8 & 34.08 & 0.95196 \\
\hline 43 & 4.8 & 0.829 & 40 & 0.48 & 33 & 32.68 & 0.9903 \\
\hline 44 & 4.8 & 0.829 & 35 & 0.5 & 30.3 & 30.94 & 1.02112 \\
\hline
\end{tabular}

\section{Discussion of Results}

Table (2) shows the main investigated parameters of the six mixes considered for the present work. It is clear from the Table that the water/cement ratios (i.e. water demand of the mix) is dependent on the standard deviation of the coarse aggregate particles, this is based on the fact that a small standard deviation means a higher percentage of the particles close to the average size, that is a low water demand, hence higher compressive strength both at $7 \& 28$ days, this is true whether graded or ungraded aggregates are used as the results of mixes $1,2 \& 3$ indicate.

A noticeable increase in the standard deviation (from 0.536 to 0.64) indicates a decrease in the strength (as shown in Fig. (5)). This is clear for mixes 4,5, and 6 of Table (2), the reason for this 
behavior being that an increase in the standard deviation indicates that a large proportion of the aggregates is in the fine fraction this is further substantiated by the higher percentages passing the average sieve size $(60,70$, and $50 \%)$ for mixes 4,5 , and 6 respectively. This means an increase in the surface area hence an increase in the water demand of the $\operatorname{mix}(\mathrm{w} / \mathrm{c}=0.56,0.59$, and 0.61 ) for mixes 4,5 , and 6 respectively.

This of course is followed by a decrease in the resulting

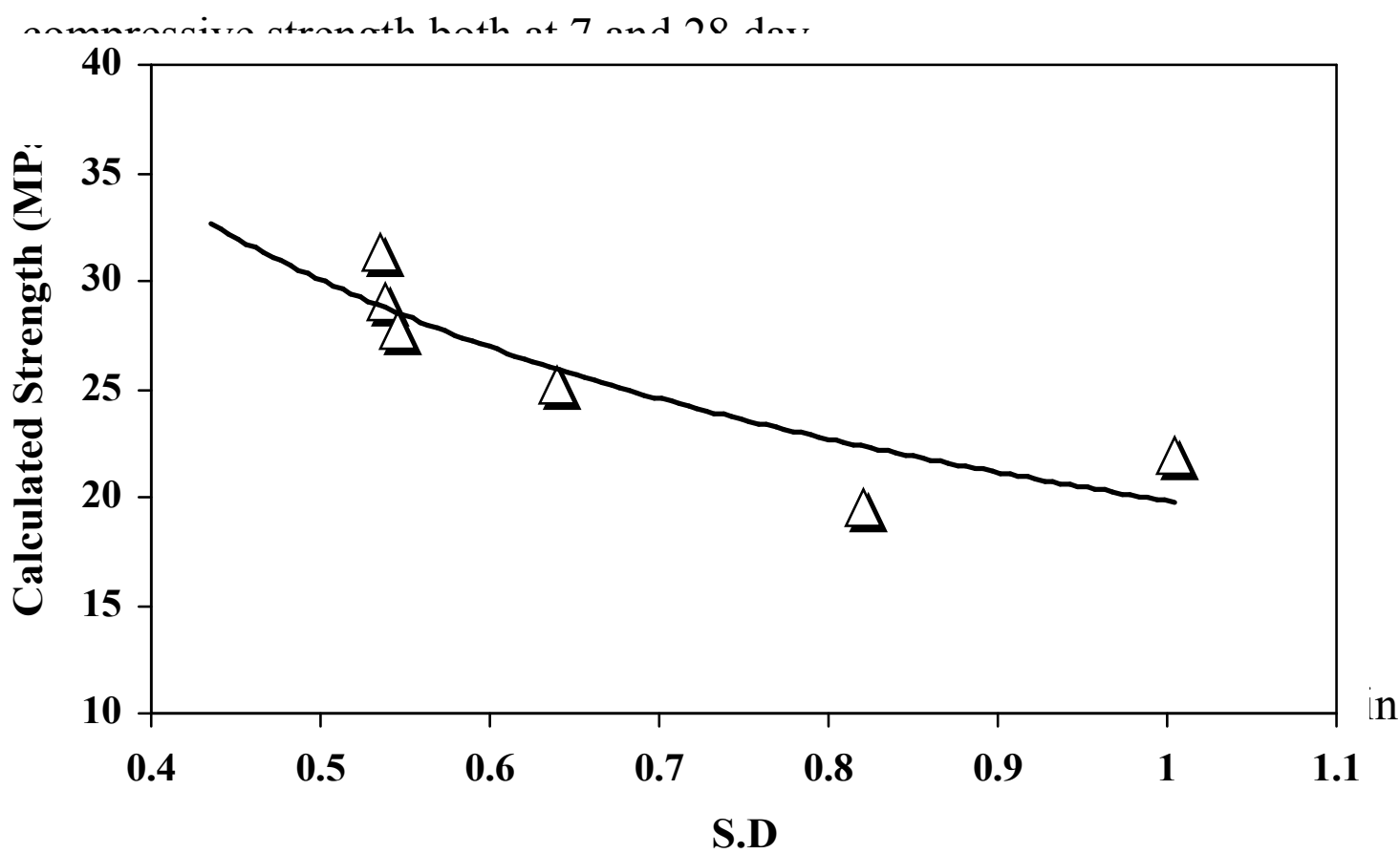

Fig.(5) Relationship between Calculated Compressive Strength and Standard

sample may be used in checking the water demand of the mix.

2. Generally speaking an increase in the standard deviation indicates a higher water demand and a strength reduction for concrete mixes.

3. An empirical estimation based on the issue of standard deviation was obtained to predict the compressive strength of concrete $(\sigma)$ with a good degree of accuracy, as given by:

$\sigma=96.69-112.1 \mathrm{~W} / \mathrm{C}-0.045 \mathrm{~S}-9.81$ S.D

\section{$\underline{\text { References: }}$}

1. Neville, A. M. "Properties of concrete", $3^{\text {rd }}$ Edition, Pitman - London 1983. 
2. Troxell G. L, Davis H. S, and Kelly J.W, "Composition and properties of concrete", 2nd Ed., Mc. Graw -Hill Book Company (1968).

3. Singh B.G, " Specific Surface of aggregate related to compressive and flexural strength of concrete ", ACI Journal, (proceeding vol. 54), vol. 29, No. 10, April (1958), pp. 897-908.

4. Murdock, L. J., "The workability of concrete ", Magazine of concrete research, vol. 12, No. 36, November 1960, Cement and Concrete Association, London, pp. 135-44.

5. Raju, N. K., "Design of concrete mixes", C.B.S publishers and distributors, Delhi (India), Second Edition, 1988.

6. B.S: 812-1960, "Methods of sampling and testing of mineral aggregates, sand and fillers", British Standards Institution, London, 1960.

7. Popvics S., "The use of the fineness modulus for the grading evaluation of aggregates for concrete ", vol. 18, No. 56, September 1966, pp. 131-142.

8. Hughes B.P., "Some factors effecting the compressive strength of concrete", Magazine of concrete research, vol. 19, No. 60, September 1967, pp. 165-172.

9. Portland Cement Association, "Design and control of concrete mixture ". Part (3), General Information, 11th Ed., July (1968).

10. AL-Rawi R.S, and AL-Murshidy K., "Effect of maximum size and surface texture of aggregate in accelerated testing of concrete", cement and concrete research, vol. 8, No. 2 (1978), pp. 201-210.

11. Walker S., Bloam D.L., and Gaynor R. D., "relationships of concrete strength to maximum size of aggregate", proceeding Highway research Board, vol. 38 (1959), pp. 367-379.

12. Ali H. A., "Effect of aggregate characteristics on fresh and hardened concrete using normal mixes", M.sc. Thesis, Dept. of civil Eng., College of Eng., Univ. of Mosul, 1988.

13. Portland Cement Association (PCA), Concrete Information, Part1" Statistical Product Concrete", June 1970.

14. Othman, S.Y.," Comparison between different mix design methods on some properties of concrete using 
local aggregates", M.sc. Thesis, University of Mosul, 1986.

15. Zakaria, K. A. A., Kashmo;a, S. Y. and Jassim B. M., "Study Effect of Total Voids Volume in the Concrete Mix on its Compressive Strength using the Accelerated Test Method." Tikrit Jour. Of Eng. Sci., Vol. 9, No. 3, Sept. 2002, pp. 19-20.

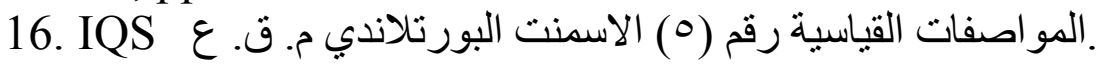

17. B.S 882-1992 "British Standard Specification for Aggregate from Natural Sources for Concrete", 1992.

\section{$\underline{\text { Appendix (A) }}$}

Typical Calculations:

1. Average sieve size: grading $20 \mathrm{~mm}$ aggregates

Col. (1) Table $(1)=\frac{0+5+70+100+100+100+100+100+100}{100}=6.75$

Fineness modulus $=6.75 \longrightarrow 7.0$

$\therefore$ Sieve index (7) is the average sieve size $=$ sieve $10\left(\right.$ col. $(3)$ Table $\left.\left({ }^{\top}\right)\right)$

2. Standard deviation

(Col. 7) ungraded 20mm max. Agg. Size (F.M =5.7)

$$
\begin{aligned}
S . D & =\frac{1}{10} \sqrt{\% \text { td on } 1 \text { st sieve(sieveindex } F . M)^{2}+\% \text { std on } 2 \text { nd siev }(\text { sieveindex } F . M)^{2}+\ldots .} \\
S . D & =\frac{1}{10} \sqrt{0(9-5.7)^{2}+5(8-5.7)^{2}+5(6-5.7)^{2}+65(5-5.7)^{2}} \\
& =1.004
\end{aligned}
$$

